\title{
Exodus, Psalms and Hebrews: \\ A God abounding in steadfast love
}

\author{
(Ex 34:6)
}

\author{
Alphonso Groenewald \\ Department of Old Testament Studies \\ University of Pretoria
}

\begin{abstract}
The author of Hebrews heavily depends on the Pentateuch and the Psalms. The Pentateuch, for the most part, offers him material for reflection on redemptive history, and the Psalms provide his Christological material. The great debt the book of Hebrews owes to the Old Testament, however, is not simply a matter of general background and copious quotation, but also extends to fundamental Old Testament ways of thinking which are constantly presupposed and which underlie all passages in the book. The concept of hesed ("faithfulness, kindness, grace, steadfast love, solidarity" etc) is one of those. According to the Hebrew Scriptures, God revealed God self to God's people at Sinai. This article will deal specifically with the reference to the Sinai revelation as it appears in three Psalms. This discussion will be followed by a short overview of this specific text in the Pentateuch. This article will be concludes by briefly indicating a possible influence these Old Testament texts on the book of Hebrews.
\end{abstract}

\section{INTRODUCTION}

The book of Hebrews resonates with the Old Testament (Attridge 2004:197). The text is an elaborate early Christian homily which was probably composed to encourage a community to remain faithful to its commitments (Punt 1997:121). In order to achieve this, the book sketches an elaborate portrait of Christ as the true high priest. It furthermore focuses on the ultimate paradigm of commitment to God. Christ's willing acceptance of the will of God earned him a place at God's right hand. This showed his followers what they must do in order to become part of the promised covenant (Attridge 2003:108). 
In an article on the use of the Old Testament in the book of Hebrews, Guthrie (2003:271) makes the following important remark: "Of all the topics in which scholarship has made strides on Hebrew research during the past quarter century, there is, perhaps, none more important that that book's uses of the Old Testament." The book of Hebrews is replete with quotations, allusions, echoes and general references from the Old Testament. Hebrews packs more of the Old Testament into its complex discourse, than any other New Testament writing. Perhaps the one exception is Revelations, which handles the Jewish scriptures quite differently. It can be simply stated that the uses to which Hebrews put the Old Testament, are the book's bone and marrow.

In the Old Testament we find the basis of authority, tools for rhetoric and exhortation, materials for building a structural framework, a wellspring for theology and, more specifically, both a professed anticipation and a validation of the book's Christology (Guthrie 2003:272). In spite of what has hitherto been said, it seems that an exact inventory of Old Testament references in Hebrews has eluded any form of consensus, due to the authors' mix of direct quotations, allusions to specific passages, uses of biblical phrases and general references to Old Testament historical events and persons. What furthermore complicates this matter is the bewildering use of terminology regarding the appropriation of the Old Testament by the New Testament in the secondary literature.

In terms of the book's employment of different parts of the scriptures, the author of Hebrews depends most heavily on the Pentateuch and the Psalms (Guthrie 2003:274). The former, for the most part, offers him material for reflection on redemptive history, and the Psalms provide for his Christological material. The great debt of the book of Hebrews to the Old Testament is not simply a matter of general background and copious quotation, but it also extends to fundamental Old Testament ways of thinking which are constantly presupposed and which underlie all passages in the book (Grogan 1998:159). The concept of hesed ("faithfulness, kindness, grace, steadfast love, solidarity" etc) is one of those. The book of Hebrews is not unique in its debt to this Old Testament concept, but is a particularly striking example of its application - especially in the manner in which it portrays Christ's mercy and compassion to the suffering church.

According to the Hebrew Scriptures God revealed God self to God's people at Sinai. God made known God's nature to them. In the subsequent section I will deal with the Psalms, and specifically with three Psalms' reference to this Sinai revelation. The will be followed by a short overview of 
this specific text in the Pentateuch. I will conclude this article by very briefly indicating a possible influence these texts had on the book of Hebrews.

\section{A GOD REVEALED AT SINAI}

Israel's definition as well as understanding of God was put to words in liturgical formulas which were formulated in a very compressed and concise manner (Zobel 1986:57). We encounter the oldest of these formulas in Exodus 34, which is a review of the Decalogue. This confession of faith about Yahweh, probably a very ancient one, had been connected with Israel's oldest perceptions of Yahweh and his relationship to those he claimed his people (Durham 1987:454). This confession may have been refined, and even expanded, by the addition of supplementary phrases in the use of it in both narrative summary and liturgy; but its beginning may be assumed to be quite old, at least as old as the early development of the use of the name "Yahweh" for confessional purposes. ${ }^{1}$

The Yahweh predication in verse 6 reads as follows: Yahweh is El rahoem, w' hinanoen êrêh afajîm w' rab-ḥesed wê-êmêt (Yahweh is "El merciful and gracious, slow to anger, and abounding in steadfast love and faithfulness"). Here, as Yahweh reveals himself, his name and his character to Moses, he states among his attributes that he is $w^{e}$ rab-hesed wê-êmêt ("abounding in steadfast love and faithfulness"). ${ }^{2}$

Yahweh's self-revelation (Ex 34:6-7) is set in the aftermath of the episode of the golden calf (Ex 32) and precedes the renewal of the covenant. ${ }^{3}$ The expression occurs in a particularly solemn context, coming from the mouth of Yahweh himself in the course of the theophany, and the prefixed rab emphasises both the solemnity of the occasion and the abundance of the

\footnotetext{
${ }^{1}$ According to Spieckermann (2000:310) "... it is obvious that it was probably used as a hymnic formula in cultic praises of God. In Exodus 34, however, it is intentionally shaped as divine speech ...". Franz (2003:153) infers as follows: "In seiner abgewogenen Verhältnisbestimmung von Zorn und Erbarmung is Ex 34, 6f ein Meisterstück von Theologen. Sie hat sich die prophetische Gotteserkenntnis zunutze gemacht und in die Form der Psalmensprache gebracht."

${ }^{2} \mathrm{Cf}$ the following remark by Houtman (1996:685): "Door de opsomming van min of meer synonieme termen komt het karakter van JHWH zeer duidelijk uit de verf: zijn doen en laten wordt gekenmerkt door buitengewone toewijding, inzet en liefde" (cf also Zenger 1982:244ff).

${ }^{3}$ Cf in this regard Scoralick (2002:89-90): "Zwischen den (nicht ausdrücklich im Text so genannten) Polen von Bundesbruch und Bundeserneuerung entfaltet sich das dramatische Geschehen. Eingebunden sind darin Elemente komplexer theologischer Reflexion zu Fragen der Gegenwart und Erfahrbahrkeit Gottes. Vorrangiges Thema der Kapitel ist das Ringen um den weiteren Bestand und die Gestalt der Beziehung zwischen JHWH und Israel nach der existenzbedrohenden Krise, die die Episode mit dem goldenen Kalb auslöste. Durch die Krise klären sich die Identitäten aller Beteiligten und ihrer Beziehung ... Der erneuerte Bund gründet in Gottes schöpferischer Barmherzigkeit und Vergebung (Ex 34, 10), deren erstes Zeichen das strahlende Mosegesicht ist."
} 
ḥesed wê-êmêt that Yahweh is lavishing on his wayward people (Clark 1993:247-8).

The confession that follows the double calling of Yahweh's name is clearly reflected in eight Old Testament passages (Durham 1987:453). ${ }^{4}$ Three of them are in the Psalms, namely Psalms 86:15, 103:8 and 145:8; and one each in Numbers 14:18; Joel 2:13; Nahum 1:3; Nehemiah 9:17 and Jonah 4:2. A word for word repetition of this formula occurs in Psalm 86:15, as well as in Psalm 103:8 (though without $E l$ and êmêt). ${ }^{5}$ This formula furthermore occurs though with a minor change in the word order and with the omission of one of the constituent parts - in Psalm 145:8. This article will however only focus on the three abovementioned Psalm texts in which this formula occurs.

\subsection{Psalm 86:15}

The specific profile of this Psalm can be defined as follows: A detailed analysis of the text of Psalm 86 with regard to its intertextuality, reveals that this psalm is an artful relecture of already existing texts (Hossfeld \& Zenger 2000:536; Tate 1990:380). The skifful intertextuality of the text presupposes both an intensive familiarity with the tradition, or with the texts incorporated, and literary-poetic competence, so that the psalm may well have originated in the milieu of scribal scholarship (Hossfeld \& Zenger 2000:539).

The creativity of the author of Psalm 86 is shown in the fact that, on the one hand, he has combined conventionalized Psalmic language in such a way that Psalm 86 appears as a summary of the "Davidic" Psalms; ${ }^{6}$ especially the partial compositions Psalms 40-41 and 69-71, 72, which conclude the two "Davidic Psalters", Psalms 3-41 and 51-71, 72, and that on the other hand, by adopting the Sinai theology of Exodus 33-34, he gives the psalm an overall horizon that then acquires further dimensions of meaning in the context of the Psalter (Hossfeld \& Zenger 2000:537).

Psalm 86, which in terms of genre criticism, can be classified as a petition, is constantly shaped as a "thou"-address to God. ${ }^{7}$ In Him the

\footnotetext{
${ }^{4}$ Cf also Dohmen (2004:354); Franz (2003:3); Fretheim (1991:302); Houtman (1996:685); Scoralick (2002:1) and Tate (1990:383).

${ }^{5}$ Kraus (1989:292) and Zobel (1982:57). Cf also Brunert (1996:142).

${ }^{6}$ According to Tate (1990:380) "the composition of Psalm 86 in terms of the skilled use of traditional material means that the title, 'Davidic prayer', must be assumed to be a scribal construct to give the psalm Davidic authority. It belongs to the tendency of LXX, Syr, and QPss mss to extend Davidic authority by the use of more Davidic superscriptions."

${ }^{7}$ Contrastingly, Gunkel \& Begrich (1985:172) and Kraus (1972:596) classify this psalm as a "lament of the individual".
} 
supplicant seeks the saving and consoling nearness of his God - making reference to God's self-revelation at Sinai. To that extent one can assert that this Psalm is at the same time a prayer clothed in Sinai theology, as well as a realised theology of prayer (Hossfeld \& Zenger 2000:538). This means that the psalm asks for rescue from hostile powers so that in and through that rescue the "nature" of Yahweh, that is formulated in the predicates, that is the mystery of his "name", will be revealed.

The focus will now be on verse 15, which is a word for word repetition of the Exodus formula. ${ }^{8}$ In this verse the petitioner appeals precisely to this specific "divine profile" of the God of Sinai, and to the "nature" of Yahweh which was revealed. Important is the fact that he reminds his God, with this quotation from Exodus 34:6, of his godhead, proclaimed by Himself and which was experienced by Israel in the story of its origins.

The fact that Israel was rescued from its misery in Egypt, and was not rejected by its God in spite of its rebellion in the wilderness and its breaking of the covenant of Sinai, but was accepted forever as the people of Yahweh's own possession, is due to these very ways of working, these very characteristics which verse 15 recalls by citation. Yahweh is "merciful": he recognises suffering as suffering and allows himself to be moved by it (Tate 1990:383). "Gracious": as one powerful and of high position, he bends down protectively, shows mercy, and cares for those in misery. "Slow to anger": he is patient and generous. And "abounding in steadfast love and faithfulness": his love is not only inexhaustible, but reliable and indestructible.

In this text of Psalm 86 the petitioner now asks for himself as an individual a demonstration of this godhead of Yahweh, revealed in the history of the people of Israel - and in such a way that his enemies may see that God is on his side, and that they are thereby publicly "shamed" - that is, disclosed and disempowered. It can be concluded by stating that Psalm 86 is theology at prayer.

\subsection{PSALM 103:8}

Psalm 103 opens a group of psalms of praise, namely Psalms 103-107 (Allen 1983:21). This psalm can be classified as a hymn praising Yahweh's kingship which was revealed at Sinai (Zenger 1997:417). Yahweh is worthy of a total

\footnotetext{
${ }^{8}$ Psalm 86:15 reads as follows: "But you are my Lord, you are a merciful and gracious God (EI), slow to anger and abounding in steadfast love and faithfulness" ( $w^{e}$ atāh Adonaj El rahoem w' ḥanoen êrêh afajîm we rab-ḥesed wê-êmêt).

${ }^{9}$ This verse reads as follows: "Yahweh is merciful and gracious, slow to anger and abounding in steadfast love" (rahoem w hạanoen Yahweh êrêh afajîm w' rab-ḥesed); thus without El and êmêt.
} 
response of grateful worship for the totality of his blessings. All the blessings and benefits listed in this text are all consistent with the age-old divine revelation. They were a creed come true. Yahweh had always been the answer to his people's needs. Hymnic motifs are thus heard which in a most comprehensive way glorify Yahweh's wonderful rule in the history of his chosen people (Kraus 1989:290).

The content of his "transcendent name" ( $v 1)$ had once and for all been revealed in the propositional statement of Exodus 34:6. Moses, in response to his plea (Ex 33:13), had received as Israel's representative a definition of the divine name in terms of Yahweh's gracious attitude towards his covenant people. ${ }^{10}$ This text of Psalm 103 constantly has as interplay the text of the Sinai account (Ex 19-34), which is here indicated as a "new covenant", i.e. a "covenant of constant renewal". We also have this perspective in the final text of Exodus 19-34 on a canonical level (Zenger 1997:417). ${ }^{11}$

What is this loyal love, this hesed? How does Psalm 103 define it? The psalmist expounds its significance in the course of verses 9-18 (Allen 1983:22). The verses 9-12 outline how the charitableness of God toward his own, predominates and eventually bids him to drop the charges he might have pressed against them. God thus forgives totally the iniquities of his own. The verses 13-18 aptly define this divine hesed in terms of pardoning love. These statements about the goodness and forgiveness of Yahweh rise to their culmination in the image chosen in verse 13, where the tertium comparationis is the merciful love of a father (Kraus 1989:292). This is the nature of the father of the covenant to welcome back his son (cf Ex 4:22; Jr 31:20; Hs 11:1, $3,4)$.

\subsection{PSALM 145:8 ${ }^{12}$}

In form Psalm 145 is an acrostic poem which begins each bicolon with a fresh letter of the Hebrew alphabet (Allen 1983:294; Franz 2003:253; Kraus 1989:546). It is clear that the form and stylistics share in elucidating the

\footnotetext{
${ }^{10} \mathrm{Cf}$ in this regard Dohmen (2004:359): "Den Kerngedanken dieser Kapitel (Ex 33-34) bringt Ps 103 in eine Gebetsform und zitiert Ex 34, 6 sogar. Mann kann diesen Psalm als ins Gebet gefasste Zinaitheologie beschreiben, wobei der Schwerpunkt deutlich auf das Motiv der göttlichen Barmherzigkeit und Vergebungsbereitschaft gelegt wird."

${ }^{11}$ In this regard Franz (2003:235) infers that it is clear that "die Parallelen von Ex 34, 6f nicht nur eine Formel vom barmherzigen und gnädigen Gott kennen, sondern auch den Kontext der Sinaiereignisse. Sie setzen auch bei ihren Hörern und Lesern die Kenntnis der Pentateuch-Tradition voraus."

${ }^{12}$ This verse reads as follows: "Yahweh is gracious and merciful, slow to anger and abounding in steadfast love" - hanoen w' rahoem Yahweh êrêh afajîm ugdal-hased.
} 
psalm's structure and message. The versatility of the psalmist is obvious: he took the acrostic pattern in his artistic stride, and found it no obstacle at all to a coherent development of his message (Allen 1983:296). This poetic technique does not only ease the memorization of the text, but indeed fulfils a theological programme (Zenger 1998:171). It gives expression to the fact that the kingship of God will be praised from "A to Z"; that is to say in abundance in space and time. It can be said that Psalm 145 is a solo hymn of exuberant praise to appreciate Yahweh's kingship (Allen 1983:297). In terms of standard genres, it can be classified as a hymn. The motifs of Yahweh's majesty and grace alternate with repeated calls for praise.

The poet of the psalm is an individual (Kraus 1989:547). He wants to encourage "all flesh" ( $v 21$ ) to praise God. In statements of praise he pays tribute to the great deeds of Yahweh. He renders homage to the majesty of the powerful and merciful God. The poet willingly owns himself to be a link in this living chain of worship of Yahweh the king, great and mighty, who is good to all. Like every monarch worthy of the name, he cares for the subjects in his realm. The creedal statement cited in verse 8 (cf Ex 34:6), a favourite text of post-exilic Judeans, is used to summarise his constant goodness. ${ }^{13}$ At the close it is given a unique twist to indicate that Yahweh's magnitude is supremely evidenced in his love.

His love, goodness and might are made known in the fact that he who was revealed as the merciful God of Sinai - is willing to forgive (Zenger 1998:170). Furthermore, he is the Creator God who is willing to uphold all who are falling and who raises up all who are bowed down (Ps 145:14). The fact that kôl ("all, totality") occurs 16x in the text, indicates the totality of God's reign. ${ }^{14}$

In the subsequent section the focus will be on the text of Exodus 34:6, which served as the pre-text for the preceding psalm texts.

\subsection{EXODUS 34:6}

Exodus chapter 34 should be read against the background of the Sinai narrative, which is narrated in Exodus chapters 19-34. It seems to be

\footnotetext{
${ }^{13}$ In this regard Franz (2003:255) infers as follows: "Nun ist Ps 145,8 traditionsgeschichtlich jünger als Ex 34, 6f. Das muss nicht breit begründet werden: Der Psalm ist sehr jung, stammt aus einem schriftkundigen Milieu und musst Ex 32-34 kennen."

${ }^{14}$ Zenger (1998:172) infers as follows in this regard: "Der Psalm will eine Theologie des Gottesreichs entfalten - und dies in der diesem Thema einzig angemessenen Form des hymnischen Lobpreises 'auf ewig und immer'. Mit diesem Psalm will der Beter (im Sinne der Psalterredaktion ist es 'David': vgl V.1a) sich einerseits einfügen in den Lobpreis des Weltkönigtums JHWHs, der (wie der Psalm dann erläutert) immer schon durch die Werke des Schöpfer- und Geschichtsgottes erklingt - allein dadurch daß und wie sie sind (Perspektive: 'das Werk lobt seinen Meister'). Andererseits will sich der Psalmsänger zum Stimmführer der Lobgesänge machen, in der er 'alles Fleisch' ( $\mathrm{vgl}$ V.21) mitreißen will und die nie verstummen sollen, weil auch das zu feiernde Königswirken JHWHs nie zu Ende geht."
} 
integrally related to the chapters $19-24$; and indeed to the entire Sinai tradition. ${ }^{15}$ On the final text's canonical level the perspective of these chapters can be summarised with the term "new covenant", which implies a "covenant of constant renewal" (Zenger 1997:417). We discern the following three phases in these chapters: (1) covenant agreement on the basis of the Decalogue and the so-called Covenant Code (Ex 19-24); (2) breaking of the covenant as a result of the worship of the golden calf (Ex 32); (3) and renewal of the covenant (Ex 33-34). ${ }^{16}$ Chapter 34 is thus built into the pattern of sin and forgiveness by joining it to the chapters 32 and $33 .{ }^{17}$ It is thus transformed into a renewal of the broken covenant and forms the climax of the narrative which began in 32 with the story of the golden calf (cf also Durham 1987:451). Chapter 32 relates the breaking of the covenant, while 34 recounts its restoration. Chapter 33 bridges the two parts of the narrative with an account of Moses' intercession which finally achieved the healing of the breach (Childs 1979:611). ${ }^{18}$ It seems clear that a blending of earlier traditions dealing with separate themes had here been accomplished deliberately and with a masterful style.

Exodus chapter 34 is one of the most difficult chapters to analyse and opinions differ widely on its interpretation (Childs 1979:604). The burning issue - which will however not be addressed in this article, as this is not the main focus of this article - turns out to be the issue of the relation of the Decalogue in Exodus 20 with the laws of chapter 34 (Childs 1979:605). Furthermore, the present narrative gives evidence of tensions in the details of the story. Once again, this is not the focus of the present article.

\footnotetext{
${ }^{15}$ In this regard Dohmen (2004:281) infers as follows: "Nach dem gewaltigen zweiten Block (Ex 25-31) im zweiten Teil des Exodusbuches (Ex 19-40), der insgesamt eine Gottesrede darstellt, wird mit Ex 32-34 (bzw. mit Ex 31,18) die Erzählung von Ex 24 fortgesetzt. Wie schon im Zusammenhang mit dem Tafelmotiv ... gesehen, verbindet den ersten Block der Sinaitheophanie (Ex 19-24) und den dritten (Ex 32-34) ein durchlaufender Erzählfaden. Gleichzeitig stehen sich beide Teile gegenüber, was schon die ersten, dann zerbrochener Tafeln und die daraufhin erneuerten, zweiten Tafeln verdeutlichen" (cf also Scoralick 2002:85).
}

${ }^{16}$ Otto (2007:56) indicates the significance of the renewal of the covenant as follows: "In der Bunderserneuerung in Ex 34 wird in der Gnadenformel vom gnädigen und barmherzigen Gott (Ex 34,6-7) die den Gotteszorn transzendierende Liebe Gottes explizit werden."

\footnotetext{
${ }^{17}$ In this regard Otto (2006:18) infers as follows: "Die Mose-Erzählungen arbeiten diffizil an der Antwort der Frage, ob aufgrund menschlicher Schuld gegen Gott die Geschichte scheitern könne, wenn Gott das Subjekt der Geschichte ist."

${ }^{18}$ Both Moses' intercession and God's reaction are important hermeneutical keys in order to understand the Sinai narrative: "Die Autoren wollen Moses Fürbitte und die damit verbundene Reaktion des barmherzigen Gottes als hermeneutischen Schlüssel für die gesamte Erzählung in Ex 32 verstanden wissen, sodass sie die Fürbitte aus dem Erzählfluss herausheben: die Barmherzigkeit Gottes transzendiere bei weitem den Zorn Gottes" (Otto 2007:56) (cf also Franz 2003:171).
} 
In chapter 34 Moses is commanded to cut two tablets of stone which were like the first ones which he had broken (Childs 1979:611; Durham 1987:451). The explicit mentioning of the first tablets ties chapter 34 closely to the golden calf incident. But, whereas the first time God himself provided the tablets, this time Moses is ordered to bring with him the tablets on which God is to write. It is emphasised that God himself would write on the tablets, and he would write the same words of the former tablets. This promise was the concrete sign that Israel had been forgiven and the relationship had been restored from God's side. ${ }^{19}$

The description of the preparation and execution of the instructions followed by the theophany is reminiscent of elements in chapter 19 both in its specific vocabulary and general description. In the morning Moses alone was to climb Mount Sinai and to present himself before God, who reveals himself in his name with a theophany $(34: 5) .{ }^{20}$ In the present end-text structure the actual theophany is portrayed as a fulfilment of Moses' request in the previous chapter to know God's ways (33:12-13) and to see His glory (33:17ff). ${ }^{21}$ Yahweh then announces that he will make a covenant on the basis of his words (chs 19-23), which he does. Moses writes down the words of the covenant (vv 27b-28a). Whereas in chapters 19-23 Moses acts as covenant mediator who seals the covenant between God and the people in a ritual of ratification, in chapter 34 God makes his covenant alone with Moses without any covenant ceremony (Childs 1979:607). Moreover, it is indicative that the chapter concludes with the tradition of Moses' ongoing function of communicating God's will to the people (34:29-34; cf 33:7ff).

The effect of placing the theophany within the context of the restoration of the covenant shifts the focus of the special revelation from the realm of an individual experience of Moses to a ratification of God's covenant relation with

\footnotetext{
${ }^{19}$ Cf Dohmen (2004:352): "Der mehrfache ausdrückliche Rückbezug auf die früheren Tafeln bestätigen, was aus dem angekündigten Vorüberzug Gottes zu erahnen ist, nämlich die Vergebungsbereitschaft Gottes und die daraus resultierende Ermöglichung der Gottesgemeinschaft. Im Unterschied zu den ersten Tafeln, die Mose in Ex 24,12 angekündigt und in Ex 31,18 übergeben wurden, kommt es Mose bei den neuen Tafeln jetzt zu, die Steine für die Beschriftung vorzubereiten."

${ }^{20}$ According to Franz (2003:175) "die Gnadenrede ist eingebunden in eine Szene, die man 'Gottesbegenung' oder 'Gottesschau' nennen kann”.

${ }^{21}$ This text reads as follows: "Moses said to the Lord ... 'Now if I have found favour in your sight, show me your ways, so that I may know you and find favour in your sight. Consider too that this nation is your people' (12-13) ... The Lord said to Moses, 'I will do the very thing that you have asked; for you have found favour in my sight, and I know you by name'. Moses said, 'Show me your glory, I pray'” (17-18) (NRSV). In this regard Dohmen (2004:354) infers as follows: "Man kann die V6-7 von hierher durchaus als Gottes Antwort auf die Bitte Mose nach dem »Wissen« um Gottes Weg $(E x 33,13)$ und das »Sehen « der Herrlichkeit Gottes (Ex 33,18 ) betrachten, wobei dann der »Vorüberzug « auf letzteres zu beziehen ist und die »Gnadenformel « auf ersteres."
} 
Israel through his mediator. The God who now makes himself known through this name as the God of mercy, steadfast love and judgement makes good his claim by forgiving his sinful people. This God - Yahweh - is a God merciful and gracious, abounding in steadfast love; His will to forgive is therefore incomprehensible for the human mind (Dohmen 2004:356). The frequent use in other parts of the Old Testament of the formula in verse 6 , by which the nature of God is portrayed, is an eloquent testimony to the centrality of this understanding of God's person. ${ }^{22}$ It seems that the biblical tradition understood the formulation as a reflection of a considerable history of Israel's relation with its God.

\section{A GOD ABOUNDING IN STEADFAST LOVE}

\subsection{An Old Testament perspective}

A rich and profound theological framework is prevalent behind the mere surface of these words - they namely indicate a specific image and understanding of God. Any text mentioning Yahweh's ḥesed ('God's steadfast love/kindness/grace") is an appeal to his gracious character and exceptional commitment to his people according to his self-revelation (Bultmann 1978:479; cf Flyysvik 1997:166). In the Old Testament, when used in religious language, it denotes an attitude of God which arises out of his relationship with his people. God's hesed thus rests on the berit by which he has freely bound Himself to his people. Hesed may be defined as follows: it "is not merely an attitude or an emotion; it is an emotion that leads to an activity beneficial to the recipient. The relative status of the participants is never a feature of the hesed act, which may be described as a beneficent action performed, in the context of a deep and enduring commitment between two persons or parties, by one who is able to render assistance to the needy party, who in the circumstances is unable to help him- or herself" (Clark 1993:267). That is to say, God's hesed is the providential exercise of his power on behalf of the needy people with whom he has established a special relationship.

Hesed is an indication of the permanence of divine kindness (Zobel 1986:62). It indicates Yahweh's benevolence in favour of Israel and the individual worshipper. The history of Yahweh's people - past, present and

\footnotetext{
${ }^{22}$ Cf the following remark by Dohmen (2004:354): "Die nun folgende "Namensoffenbarung « enthält keine Wesensbeschreibung Gottes, wie man sie im Horizont der Theophanie vielleicht erwartet. Vielmehr ist das, was man zwar durchaus wie eine theologisch reflektierte CredoFormulierung betrachten kann, eingentlich eine "Gottesbeschreibung «, die in ihrem ersten Teil ... aus einer Beziehung heraus oder auf eine solche hin formuliert ist."
} 
future; the life of the individual Israelite - in fact, of the whole world - is the stage where Yahweh demonstrates his kindness. He has decided in favour of Israel; he has promised life, care, alleviation of distress, and preservation indeed, he has filled the whole earth with his kindness. He has thus granted fellowship to his people, to all mankind, to the whole world. And this act, like the promise and assurance of future help and fellowship, is characterised by permanence, constancy and reliability. This is what Israel and the individual Israelite hear through Yahweh's word.

\subsection{A Septuagint (LXX) perspective}

Normally the LXX uses eleos for hesed - this is also the case in our text of Exodus 34:6. The LXX translators have rendered the Hebrew rab-hesed with polu'eleos ("very compassionate"). In religious usage hesed always means his faithful and merciful help, and this understanding is also expressed in the use of eleos in the LXX (Bultmann 1978:479; Esser 1992:594). Because of Yahweh's superiority as the partner in the covenant who remains faithful, his eleos was understood for the most part as a gracious gift. He promised it at the making of the covenant, and he constantly renewed it. Hence Israel may request eleos from him, including the mercy of forgiveness, when it had broken the covenant (e g Ex 34:9; Nm 14:19; Jr 3:2). When God acts like this and also when man acts similarly, the stress is not on the basic attitude, but on its manifestations in deeds.

\subsection{A New Testament perspective}

In the New Testament eleos is often used for the divinely required attitude of man to man (Bultmann 1978:482). However, more important regarding our specific discussion, is the New Testament's understanding of God's eleos, which is often thought of in the original Old Testament sense of "faithfulness", i.e. the gracious faithfulness of God - thus in the same way than hesed. When God's eleos is mentioned, it is most often expressed with reference to the Christ event. It marks that breaking in of the divine mercy into the reality of human misery which took place in the person of Jesus of Nazareth with his work of freeing and healing which demonstrated his authority (Esser 1992:595). Jesus answered the cry for help: "Have mercy on me" (Mk 10:47, 48). In the prologue to his Gospel, Luke announced its main theme in the two great psalms of praise (Lk 1:46-55, 68-79), namely that the covenant loyalty of God, as promised in the Old Testament and shown in action in the history of Israel, would reach its climax in the gracious self-humiliation of God the humble ("poor") in the event of Christ. 


\section{CONCLUSION}

The book of Hebrews uses the Old Testament (specifically texts from the Pentateuch and from the Psalms) in many and diverse ways (Attridge 2004:212). These texts are used as a structuring element for the discourse as a whole, articulating its major segments and serving as an essential component to substantiate its innovative Christology. It is thus used as evidence along the way for various contentions that the homilist wants to make about the person and work of Christ and the kind of response required for his followers. Most intriguing is the fact that these texts are used to give a voice to Jesus. Ironically, the one who delivers the final word of God to the world speaks in the book of Hebrews only in the words of scripture - that is the Old Testament - and principally in the words of the Pentateuch and the Psalms.

The great debt of the book of Hebrews to the Old Testament is not simply a matter of general background and copious quotation, but the way in which it also extends to fundamental Old Testament ways of thinking, which are constantly presupposed and which underlie all passages in the book. In the book of Hebrews we thus often detect references, whether direct or even indirect, to the Old Testament as an authoritative text(s). The Old Testament texts give voice to the aims and aspirations of Jesus. Christ, by whom God has now spoken his final word (Heb 1:1), had always been alive and active throughout Israel's history. Any part of the Old Testament may thus in principle be understood as speaking about Christ, or as spoken to or by him.

Whenever the author portrays the character of Jesus, the concept of God, as made known to us in Exodus 34:6 (and as quoted in the Pss 86:15; $103: 8 ; 145: 8)$ plays an important role in his theologizing about Jesus. Already at the beginning of the book the author portrays Jesus as a reflection of the glory of God and - very important - the exact imprint of God's very being (Heb 1:3). The Old Testament texts which were discussed in this paper say something to us about Israel's understanding of Yahweh's very being. Hebrews, in its portrayal of Christ as a type of high priest, uses the concept eleos (hesed) to show the solidarity of Christ, who is greater than any high priest, with his brethren (2:17). ${ }^{23}$ This is a guarantee of Christ's merciful and boundless significance for the first century flesh-and-blood believers struggling to overcome the stranglehold of past traditions and adjust to the fresh movements of God in their fast-changing world.

\footnotetext{
${ }^{23}$ Hebrews 2:17 reads as follows: "Therefore he had to become like his brothers and sisters in every respect, so that he might be a merciful (ele'ēmōn) and faithful high priest in the service of God, to make a sacrifice of atonement for the sins of the people" (NRSV).
} 
According to $4: 16$ this fact gives the despairing church confidence to draw near the throne of grace in order to find mercy - as the new Israel (Esser 1992:598; cf also Enns 1997:358). ${ }^{24}$ They are witnesses to the climax of God's covenant relationship with his people - first Israel, now the church. This statement reflects the homilist's experience - what he has seen with the eyes of faith. He wraps his experience in Old Testament terms, offering a new Christological reading of the Old Testament based on the fundamental conviction about the ultimate significance of Christ as the one abounding in steadfast love (eleos).

The ultimate meaning of Scripture is therefore defined in terms of their own privileged position in the unfolding drama of history. Whatever these Old Testament texts might have meant at an earlier time, the author of Hebrews tells his readers that its ultimate and therefore proper meaning concerns the church's participation in God's eleos (hesed), both now amid certain trouble and temptation, and later in the world to come for those who remain faithful.

Our homilist is thus at great pains throughout his text in this book to see how the Word of God in the scriptures (that is, the First Testament) can speak to the reality of his addressees. Imaginative exegesis helps him along the way to find fresh meaning in the old texts in order to invite his audience to imitate the "initiator and perfecter" of their faith - that is the true high priest Jesus.

\section{Works consulted}

Allen, L C 1983. Psalms 101-150. Waco, TX: Word Books. (WBC 21.)

Attridge, H W 2003. Giving voice to Jesus: use of the Psalms in the New Testament, in Attridge, H W \& Fassler, M E (eds), Psalms in community: Jewish and Christian textual, liturgical, and artistic tradition, 101-112. Atlanta, GA: Society of Biblical Literature. (Symposium Series 25.)

Attridge, H W 2004. The Psalms in Hebrews, in Moyise, S \& Menken, M J J (eds),

The Psalms in the New Testament, 197-212. London: T\&T Clark. (The New

Testament and the Scriptures of Israel.)

Brunert, G 1996. Psalm 102 im Kontext des Vierten Psalmenbuches. Stuttgart:

Katholisches Bibelwerk. (Stuttgarter Biblische Beiträge 30.)

Bultmann, R 1978. $s v$ eleos, etc. TDNT, 9th edition.

Childs, B S 1979. Exodus, 3rd edition. London: SCM. (OTL.)

Clark, G R 1993. The word hesed in the Hebrew Bible. Sheffield: Sheffield Academic Press. (JSOT SS157.)

Crogan, G W 1998. The Old Testament concept of solidarity in Hebrews. TynB 49(1_, 159-173.

\footnotetext{
${ }^{24}$ Hebrew 4:16 reads as follows: "Let us therefore approach the throne of grace with boldness, so that we may receive mercy (eleos) and find grace to help in time of need" (NRSV).
} 
Dohmen, Chr 2004. Exodus 19-40. Freiburg: Herder. (HThKAT.)

Durham, J I 1987. Exodus. Waco, TX: Word Books. (WBC 3.)

Enns, P 1997. The interpretation of Psalm 95 in Hebrews 3:1-4:13, in Evans, C A \& Sanders, J A (eds), Early Christian interpretation of the scriptures of Israel: Investigations and proposals, 352-363. Sheffield: Sheffield Academic Press. (JSNTS 148.)

Esser $\mathrm{H}-\mathrm{H}$ 1992. $s$ veleos (mercy, compassion). DNTT.

Flpysvik, I 1997. When God becomes my enemy: The theology of the complaint Psalms. Saint Louis, MI: Concordia Academic Press.

Franz, M 2003. Der barmherzige und gnädige Gott: Die Gnadenrede vom Sinai (Exodus 34,6-7) und ihre Parallelen im Alten Testament und seiner Umwelt. Stuttgart: Kohlhammer. (BWANT 160.)

Fretheim, T E 1991. Exodus. Louisville, KY: John Knox. (Interpretation.)

Gunkel, H \& Begrich, J [1933] 1985. Einleitung in die Psalmen: die Gattungen der religiösen Lyrik Israels. 4. Auflage. Göttingen: Vandenhoeck \& Ruprecht.

Guthrie, G H 2003. Hebrews' use of the Old Testament: Recent trends in research. Currents in Biblical Research 1(2), 271-294.

Hossfeld F-L \& Zenger, E 2000. Psalmen 51-100. Freiburg: Herder. (HThKAT.)

Houtman, C 1996. Exodus 20-40, Deel III. Kampen: Kok. (COT.)

Kraus, H-J 1972. Psalmen 64-150. 4. Auflage. Neukirchen-Vluyn: Neukirchener Verlag. (BKAT XV/2.)

Kraus, H-J 1989. Psalms 60-150. A commentary, tr by H C Oswald 1989. Psalmen 60-150. 6. Auflage. Neukirchen-Vluyn: Neukirchener Verlag. (BKAT XV/2.) Minneapolis, MN: Augsburg.

Otto, E 2006. Mose - Geschichte und Legende. München: C H Beck.

Otto, E 2007. Das Gesetz des Mose. Darmstadt: WBG.

Punt, J 1997. Hebrews, thought-patterns and context: Aspects of the background of Hebrews. Neutestamentica 31(1), 119-158.

Scoralick, R 2002. Gottes Güte und Gottes Zorn: Die Gottesprädikationen in Exodus 34, 6f und ihre intertextuellen Beziehungen zum Zwölfprophetenbuch. Freiburg i.B.: Herder. (HBS 33.)

Spieckermann, H 2000. God's steadfast love: Towards a new conception of Old Testament theology. Bib 81, 305-327.

Tate, M E 1990. Psalms 51-100. Waco, TX: Word Books. (WBC 20.)

Zenger, E 1982. Das Buch Exodus. 2. Auflage. Düsseldorf: Patmos Verlag. (Geistliche Schriftlesung.)

Zenger, E 1997. Die Nacht wird leuchten wie der Tag. Psalmenauslegungen. Freiburg i.B.: Herder.

Zenger, E 1998. Dein Angesicht suche ich. Neue Psalmenauslegungen. Freiburg i.B.: Herder.

Zobel, H-J 1986. s $v$ hesed. TDOT. 